\title{
Schwannoma of the Prostate: A Rare Case Report and Literature Review
}

Oktay Üçer *, Mehmet Fatih Zeren, Mehmet Fatih Kuyumcuoğlu and Murat Lekili

Department of Urology, Faculty of Medicine, Celal Bayar University, Turkey

*Corresponding author: Oktay Üçer MD, Faculty of Medicine, Celal Bayar University, Turkey, Tel: + 90 505 211-4618; E-mail: uceroktay@yahoo.com

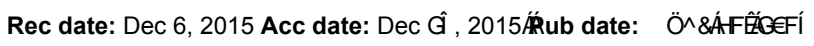

Copyright: () 2016 Üçer O, et al. This is an open-access article distributed under the terms of the Creative Commons Attribution License, which permits unrestricted use, distribution, and reproduction in any medium, provided the original author and source are credited.

\begin{abstract}
Introduction: We present a case of a schwannoma that originated in a prostate. It is very rare location presenting Schwannoma.

Case report: A 64-year-old man presented with severe lower urinary tract symptoms. On digital rectal examination, there was a grade 3 enlarged prostate without nodules and tenderness. The transrectal ultrasonography revealed that prostate volume was $200 \mathrm{cc}$. Retroperitoneal transvesical prostatectomy was performed because of huge prostatic enlargement. Histopathology showed schwannoma of prostate.

Conclusion: Owing to the lack of characteristic clinical manifestation, the final diagnosis of prostate schwannoma relies on postoperative pathological examination.
\end{abstract}

Keywords: Prostate; Schwannoma; Prostatectomy

\section{Introduction}

Schwannomas are rare tumors originated from the schwann cell of the peripheral nerve sheaths. Commonly accompanies to von Reclinghousen's disease (neurofibromatosis type 1). Generally occurs in young and middle-aged adults and the common locations include head, neck, extremities, mediastinum and retroperitoneum and rarely the male genital system [1]. They are usually asymptomatic until they become large space-occupying lesions, then the symptoms depend on the site and dimension of the tumor [2]. Herein our report is about a schwannoma of the prostate which thought to be a benign prostate hyperplasia $(\mathrm{BPH})$ patient before surgery and histopathologic examination.

\section{Case Report}

A 64-year old man presented with severe lower urinary tract symptoms (LUTS). Digital rectal examination revealed grade 3 enlarged prostate without nodules and tenderness. Serum PSA was $2.1 \mathrm{ng} / \mathrm{mL}$. Uroflowmetry indicated lower urinary tract obstruction. (Q-max: $5.6 \mathrm{ml} / \mathrm{sec}$ ). Transrectal ultrasonography (TRUSG) revealed prostatic hypertrophy (prostate volume was $200 \mathrm{cc}$ ) and postvoid residual urine volume was $240 \mathrm{~mL}$. Our preoperative diagnosis was $\mathrm{BPH}$ and transvesical suprapubic prostatectomy was performed.

Macroscopic examination revealed necrotic gray white tissue fragments estimated $500 \mathrm{cc}$ all including gray hard tissues. Some fragments were fragile. On microscopic examination, we determined the spindle cells were marked by interlacing fascicles, nuclei with tapered ends and prominent mitotic activity ( 25 at $10 \mathrm{hpf}$ ), geographic tumor necrosis and focal hemorrhage (Figure 1).

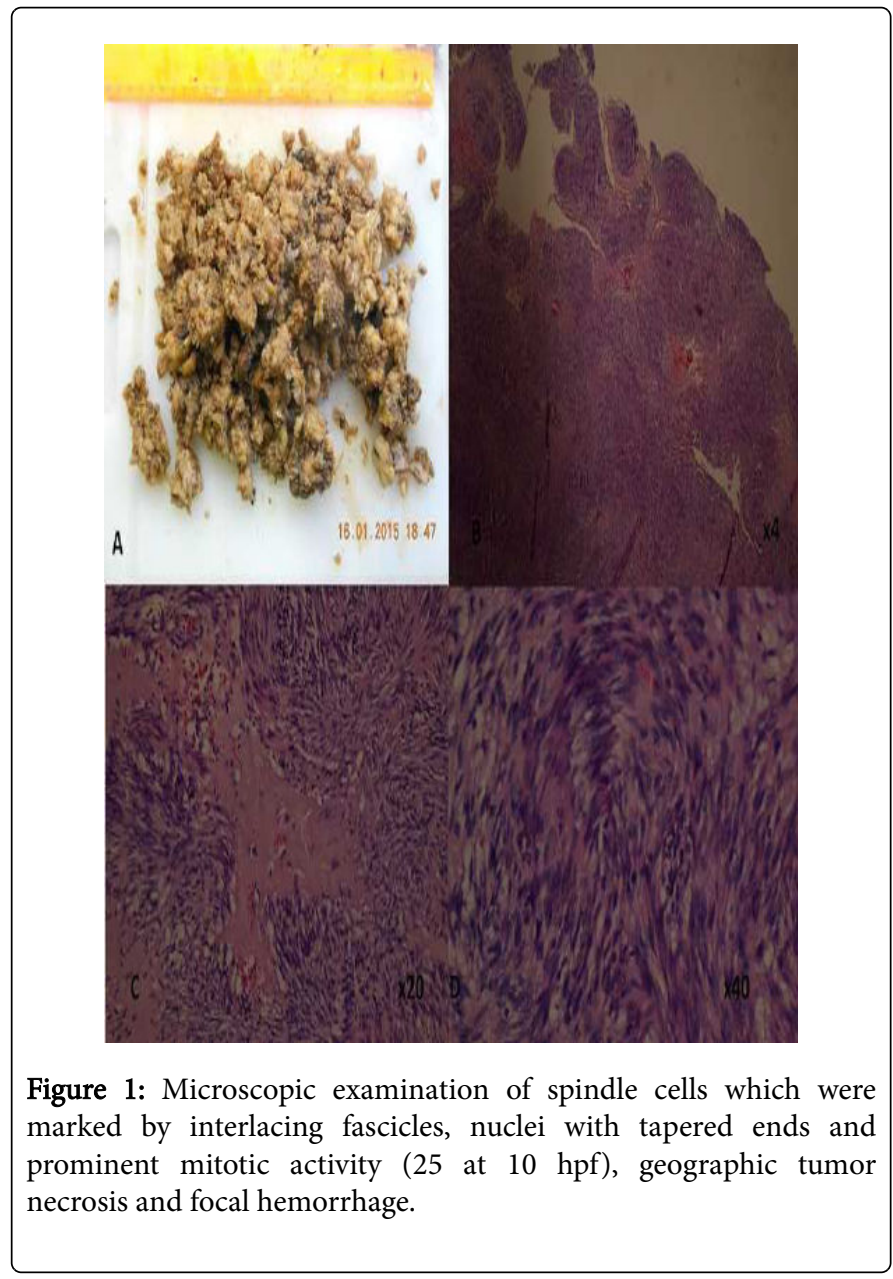


Next to the necrotic tumor tissue ordinary prostate asinuses and stroma were sighted. Immunohistochemically we observed ++ staining with S100 and vimentin in the tumor cells. According to these histological and immunohistochemical findings our diagnosis for this case was a schwannoma of the prostate. After the diagnosis our patient underwent a detailed screening for neurofibromatosis type 1 but no other findings came through. Our case is alive with no evidence of recurrence on his 18 months follow up. The patient provided written consent to use the information for the case report.

\section{Discussion}

Schwannomas generally are seen in young and middle-aged adults and few and far between in the male genital system. To our knowledge this is the fourth case of schwannoma of prostate in literature. Schwannomas are usually benign, solitary and slow growing lesions. These features were also seen in all prostate schwannoma cases in literature, all three cases were diagnosed as BPH before surgery or biopsy and histopathology because of schwannomas' general features signified above [1-3]. Malignant schwannomas will accompany with Von Reclinghausen's disease.

The clinical and radiographic findings of the prostate schwannoma are non-specific and usually misdiagnosed as BPH. They are usually silent until they are large enough to compress the urinary tract and finally LUTS occur. USG, computer tomography (CT) or magnetic resonance (MR) will be helpful to determine the size of the mass also when the diagnose become definite as schwannoma a careful search for Von Reclinghausen's disease should be performed by CT or MR imaging. In our case no accompanying findings of Von Reclinghausen's disease had seen as all three cases in literature [1-3].

The definite diagnose is generally after histopathologic and immunohistochemical examination. During surgical exploration the benign schwannoma of the prostate are generally well-demarcated, circumscribed, encapsuled and not adhering to the adjacent tissues as so during our surgery. The pressure necrosis of the surrounding tissues means poor prognosis and suggests the schwannoma is malignant.

Schwannomas are not sensitive to either radiation therapy or chemotherapy so surgical excision is the therapy of choice. Although they are very rare schwannomas should be added to the list of nodular lesions of prostate. Every patient thought to be BPH preoperatively or pre biopsy may end up as a schwannoma of prostate after histopathology.

\section{References}

1. Jiang R, Chen JH, Chen M, Li QM (2003) Male genital schwannoma, review of 5 cases. Asian J Androl 5: 251-254.

2. Francica G, Bellini S, Miragliuolo A (2003) Schwannoma of the prostate: ultrasonographic features. Eur Radiol 13: 2046-2048.

3. Rane A, Juhasz A, McEwan A, Mene A (1995) A urological diagnostic conundrum: schwannoma masquerading as an enlarged prostate. $\mathrm{Br} \mathrm{J}$ Urol 75: 683-684. 